\title{
Meio ambiente, poluição e reciclagem
}

\author{
Autoras: Eloisa Biasotto Mano, Élen B. A. V. Pacheco e Cláudia M. C. Bonelli
}

O livro aborda o meio ambiente, a poluição e a reciclagem. As autoras tratam o tema de forma clara, objetiva e de fácil compreensão, de maneira que os leitores que não são familiarizados com a terminologia técnica podem entendê-lo.

É um livro que pode ser adotado nas disciplinas de Ecologia, Ciências do Ambiente, Introdução à Engenharia Ambiental ou similares em cursos de graduação, pois é introdutório e permite induzir discussões e incentivar debates sobre as questões ambientais no mundo e no Brasil. Com relação à reciclagem, as autoras abordam apenas a questão dos plásticos, tendo em vista que elas desenvolvem pesquisas nessa área.

O livro apresenta prefácio, agradecimentos e 14 capítulos, totalizando 182 páginas. No final de cada capítulo, encontra-se a bibliografia recomendada. Os destaques estão nos seguintes pontos a serem observados:

- Capítulo 1 - A Natureza e o Planeta Terra: trata da relação entre a colonização e a natureza, hipótese de Gaia, sistema solar e o planeta Terra;

- Capítulo 2 - O Planeta e a Terra: é tratada a estrutura interna do globo terrestre e a superfície terrestre;

- Capítulo 3 - O Planeta e a Água: trata da água doce e da salgada;

- Capítulo 4 - O Planeta e o Ar: as autoras cuidam das camadas da atmosfera, do clima e do vento;

- Capítulo 5 - A Vida na Terra: aborda o modo como ocorreu o início da vida na Terra e a migração do homo sapiens pelos continentes;

- Capítulo 6 - A Poluição Ambiental: definição de 'poluição', o que gera seu aumento, além de abordar também alguns fenômenos, como o efeito estufa e o buraco na camada de ozônio;

- Capítulo 7 - As Principais Fontes de Energia: trata das fontes de energia convencionais, como petróleo, gás natural, carvão e energia hidrelétrica;

- Capítulo 8 - Outras Fontes de Energia: são abordadas as fontes alternativas de energia, como os ventos, o sol, a biomassa, o urânio, o oceano, a geotermia e o hidrogênio;

- Capítulo 9 - O Desenvolvimento Sustentável: são tratados temas como educação ambiental, os protocolos de Montreal e Kyoto e o desenvolvimento social, ambiental e econômico;

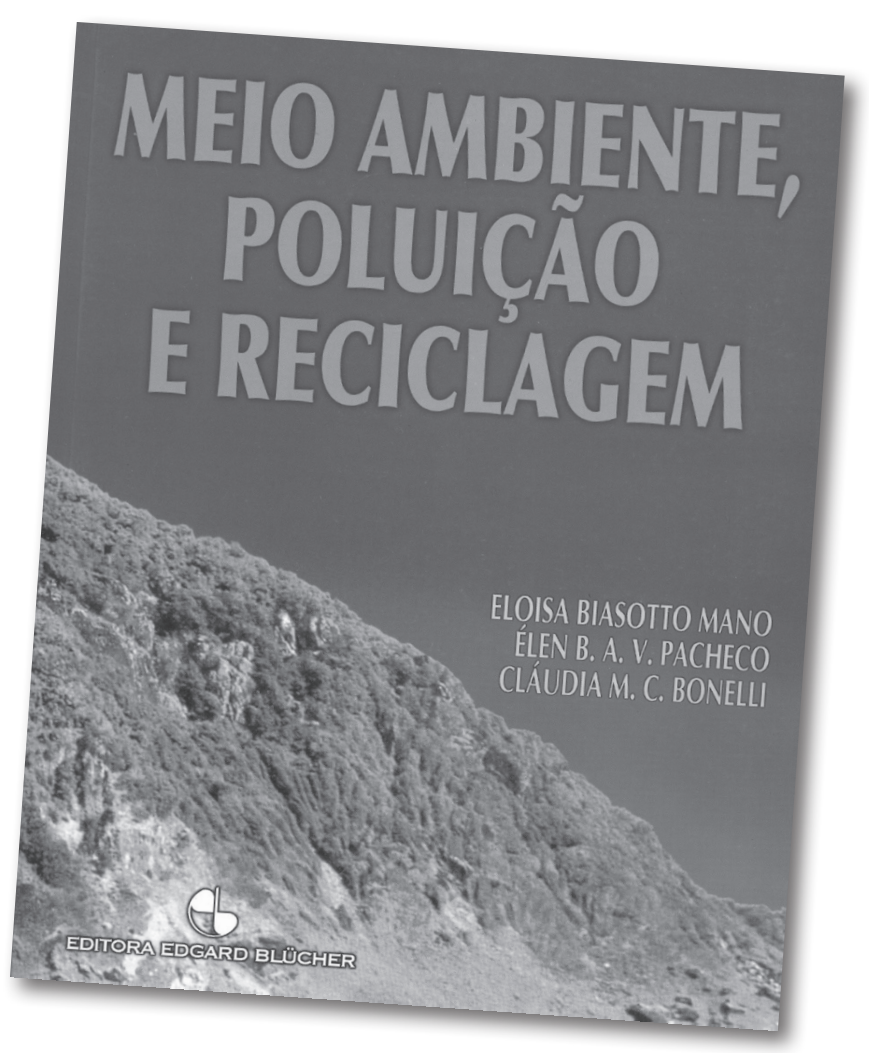

- Capítulo 10 - Os Componentes do Lixo Urbano: são tratados o conceito dos resíduos sólidos (lixo), sua classificação e composição;

- Capítulo 11 - O Gerenciamento dos Refugos Urbanos: trata do gerenciamento dos resíduos sólidos urbanos, abordando a questão dos três Rs (reduzir, reutilizar e reciclar), da coleta seletiva e da destinação do lixo;

- Capítulo 12 - Os Resíduos Plásticos: aborda a produção e o consumo de artefatos plásticos, a degradação ambiental dos plásticos e a degradação dos mesmos por reprocessamento;

- Capítulo 13 - A Reciclagem de Plásticos: trata dos tipos de reciclagem existentes para os plásticos e dá ênfase à reciclagem mecânica;

- Capítulo 14 - Destaques: ênfase aos tópicos de cada capítulo julgados mais importantes.

\section{Comentário elaborado por Claudia Coutinho Nóbrega. Coordenador da Coluna Livros: Cícero Onofre de Andrade Neto}

A seção "Livros", que a cada edição traz resumos comentados sobre livros de interesse na área, tem como principal objetivo permitir que o leitor, de forma rápida, se atualize e conheça o que há disponível no mercado editorial. As contribuições deverão ser encaminhadas para: resa@abes-dn.org.br 